\title{
Effect of slackwater areas on the establishment of plankton communities (testate amoebae and rotifers) in a large river in the semi-arid region of northeastern Brazil
}

\author{
Pablo H. S. Picapedra ${ }^{1, *}$, Cleomar Fernandes ${ }^{1}$, Gilmar Baumgartner ${ }^{1}$ and Fábio A. Lansac- \\ Tôha ${ }^{2}$ \\ ${ }^{1}$ Grupo de Pesquisas em Recursos Pesqueiros e Limnologia, Universidade Estadual do Oeste do Paraná, Rua da \\ Faculdade, 645, 85903-000, Toledo, PR, Brazil. \\ 2 Núcleo de Pesquisas em Limnologia, Ictiologia e Aquicultura, Universidade Estadual de Maringá, Avenida \\ Colombo, 5790, 87020-900, Maringá, PR, Brazil. \\ * Corresponding author: pablo_picapedra@hotmail.com
}

Received: 28/09/16

Accepted: 01/04/17

\begin{abstract}
Effect of slackwater areas on the establishment of plankton communities (testate amoebae and rotifers) in a large river in the semi-arid region of northeastern Brazil

The increase in discharge of rivers over time and space poses challenges to the establishment of some biotas, because of higher turbulence, turbidity, hydraulic forces and limited food sources, which may directly affect the community structure. In this context, slackwater areas play an important role in the establishment of organisms, acting as refuges, reducing turbulence, turbidity and providing greater availability of food. This study investigated the changes in community structure of testate amoebae and rotifers in relation to the appearance and disappearance of slackwater areas formed by sandbars on a stretch of the Parnaíba River. The appearance of slackwaters promoted suitable environmental conditions for the establishment of rotifers. On the other hand, slackwaters acted as a buffer for testate amoebae, allowing them to colonize the plankton due to a lower suspension of sediment in these areas. We suggest that the intermittent presence of slackwaters in the Parnaíba River channel is an essential driver of abundance and succession patterns of species in the plankton, through the alternation of washing-out effects, taxon-specific potential of reproduction and biological interactions.
\end{abstract}

Key words: colonization, current velocity, environmental variables, Parnaíba River, zooplankton

\section{RESUMO}

Efeito de áreas de baixo fluxo no estabelecimento de comunidades planctônicas (amebas testáceas e rotíferos) em um grande rio na região semi-árida do nordeste do Brasil

O aumento da descarga de rios ao longo do tempo e espaço coloca desafios ao estabelecimento de algumas biotas, devido uma maior turbulência, turbidez, forças hidráulicas e limitadas fontes de alimento, que podem afetar diretamente a estrutura da comunidade. Neste contexto, as áreas de baixo fluxo desempenham um papel importante no estabelecimento de organismos, agindo como refúgio, reduzindo a turbulência, turbidez e proporcionando uma maior disponibilidade de alimento. Este estudo investigou as mudanças na estrutura de comunidades de amebas testáceas e rotíferos em relação ao surgimento e desaparecimento de áreas de baixo fluxo formadas por bancos de areia em um trecho do rio Parnaíba. O surgimento de áreas de baixo fluxo promoveu condições ambientais adequadas para o estabelecimento de rotíferos. Por outro lado, essas áreas atuaram como um tampão para as amebas testáceas colonizarem o plâncton, devido uma menor suspensão do sedimento. Sugerimos que a ausência e a presença de bancos de areia no canal do rio Paranaíba são cruciais para os padrões de abundância e sucessão de espécies no plâncton, através da alternância de 
efeitos de "lavagem", potencial reprodutivo espécie-específico e interações biológicas.

Palavras chaves: colonização, velocidade de corrente, variáveis ambientais, rio Parnaíba, zooplâncton

\section{INTRODUCTION}

Several studies have demonstrated the role of slackwater areas for the establishment of microfauna in river environments (Thorp \& Mantovani, 2005; Humphries et al., 2006; Nielsen \& Watson, 2008). Slackwaters are often formed by permanent islands, tree trunks and rocks or even by macrophyte stands, and are important refuge habitat patches for biota (Humphries et al., 2006). The dynamic nature of these habitats is driven mainly by the flow regime (Hill et al., 1991) and has been an important factor related to variability in abundance and biomass of planktonic communities (Nielsen et al., 2010).

The shorter water retention in river channels is often considered the factor responsible for the lower abundance of organisms (Pace et al., 1992). In contrast, associations of slackwater areas with the main channel of rivers have been increasingly recognized as responsible for the secondary productivity of rivers (Nielsen \& Watson, 2008). Studies investigating the secondary productivity in slackwaters indicate that these habitats contain a diverse and abundant range of organisms, mainly due to decreased water velocity, with the abundance of organisms frequently higher in slackwater areas compared to the river channel (Ward \& Stanford, 1995; King, 2004; Pace et al., 1992). However, these studies have been conducted in rivers with stable hydrological characteristics, unlike the case of rivers in semi-arid regions. Furthermore, the rivers previously studied are usually characterized by the presence of permanent islands and slackwater areas; few studies have demonstrated the effect of ephemeral islands (e.g., formed by sandbars) on the plankton community structure (e.g., Thorp \& Mantovani, 2005).

Rivers in the Brazilian semi-arid region are physically rigorous and little favorable for the establishment of planktonic communities due to instability of the sand substrate and high load of suspended sediment. The Brazilian semi-arid region is relatively dynamic, characterized by the predominance of intermittent rivers and streams, complex weather patterns, low and unevenly distributed rainfall and low thermal amplitude (Maltchik \& Medeiros, 2006; Medeiros et al., 2011; Lucena et al., 2015; Picapedra et al., 2017). As a result, many of the tributaries of the Parnaíba River have characteristics ranging from extreme flooding to drought, which contributes to a high degree of spatial variation and habitat heterogeneity (Medeiros et al., 2011). Thus, determining the factors that control the abundance, diversity and distribution of zooplankton can be an important step to understand the ecology of rivers in this region.

Testate amoebae and rotifers have long been recognized as a critical component of freshwater ecosystems, yet information on their ecology and distribution is still limited (Bertani et al., 2011; Schwind et al., 2016a). This is due to issues like inadequate taxonomic and molecular knowledge on the species, difficult identification related to phenotypic plasticity and cryptic speciation as well as insufficiency of reliable biogeographical studies (Segers, 2008; Lahr et al., 2014). These groups consist mostly of organisms with short generation times and rapid reactions to changes in environmental conditions (Bertani et al., 2011; Arrieira et al., 2015). These responses depend on several factors, such as temperature, nutritional conditions, availability and quality of food resources and population abundance (Pennak, 1953). The identification of different time scales is a prerequisite for understanding the factors and processes that characterize ecosystems and promote the variability in community structure (Levin, 1992; Thrush et al., 1997).

Thus, the present study investigated the variation in the community structure of testate amoebae and rotifers between the hydrological periods in the Parnaíba River channel. We assumed that: (i) the structure of communities of testate amoebae and rotifers is driven differently between the hydrological periods, due to the appearance and disappearance of slackwater areas resulting from the formation of sandbars; (ii) the similarity of communities between environments is greater during the high water period, since the displace- 


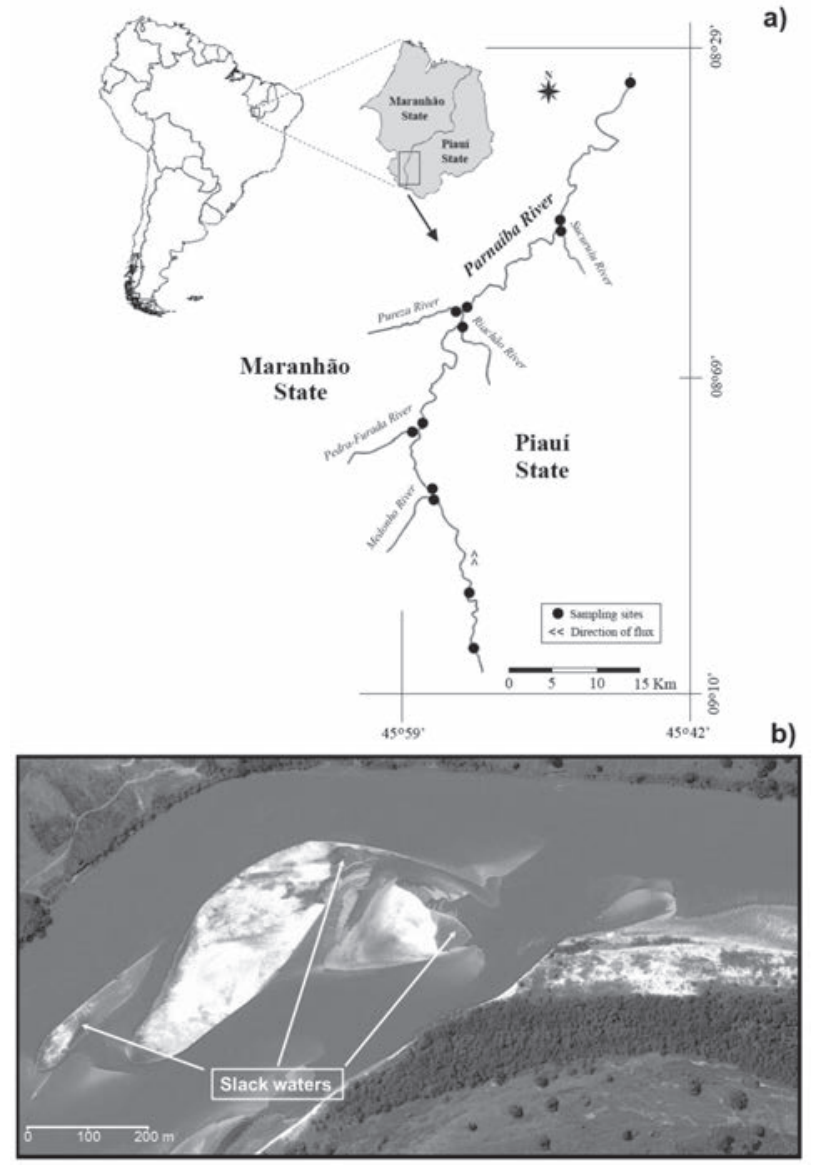

Figure 1. Location of sampling sites in the Upper Parnaíba river (a); Photograph of the Parnaíba River illustrating some of the many areas of ephemeral water retention (slackwaters) formed by islands of sandbars that appear during the dry period and disappear with the floods (b), Source: Google Earth (2013). Localização dos pontos de amostragem na região do alto rio Parnaíba (a); Fotografia do rio Parnaíba ilustrando algumas das muitas áreas de retenções hidrológicas efêmeras (slackwaters) formadas por ilhas de bancos de areia que aparecem durante a seca e desaparecem com as inundações (b).

ment of these organisms between the benthic and littoral regions is higher during this period.

\section{MATERIALS AND METHODS}

\section{Study area}

The Parnaíba River is the largest river completely located in the northeastern region of Brazil, with approximately 1432 kilometers length and a drainage area of approximately $344112 \mathrm{~km}^{2}$ (Lucena et al., 2015). This river can be divided into upper, middle and lower portion; the study area is located in the upper stretch (Fig. 1a). The region is in a transition area between the semi-arid (Bsh) and tropical (Aw) climates (Peel et al.,
2007). Rainfall varies from 600 to $1800 \mathrm{~mm}$, the vegetation consists of savannah elements associated with Cerrado and Caatinga biomes, and most of the rivers and streams of the region are intermittent (Brasil, 2006; Lucena et al., 2015; Beuchle et al., 2015). In the present study, seasonal variations in water level and hydrological regime were found to influence morphometry and the habitat structure of the study sites. During the low water period, islands formed by sandbars appear in the riverbed. The steep slope of the Parnaíba River promotes the displacement of large amounts of sediment. This sediment is deposited at certain sites and form islands, which eventually promote areas with low water flow (Fig. 1b). 


\section{Sampling}

Sampling was conducted at 12 sites located in the Parnaíba River in two hydrological periods: low water period (August 2013 - with sandbars) and high water period (January 2014 - without sandbars) (Fig. 1). Samples were taken with the aid of a suction pump to draw 600 liters of water per sample, which were filtered through a conical-cylindrical net $(68 \mu \mathrm{m})$. The collected material was placed in a polyethylene bottle $(500 \mathrm{ml})$, labeled and fixed in $4 \%$ formaldehyde solution buffered with sodium borate $\left(\mathrm{Na}_{3} \mathrm{BO}_{3}\right)$. The following environmental variables were measured: depth of the sampling sites (m); water current velocity (m/s; mechanical flow meter), water transparency (cm; Secchi disk), water temperature $\left({ }^{\circ} \mathrm{C}\right.$; mercury bulb thermometer), dissolved oxygen (mg/L; portable oxymeter), electrical conductivity $(\mu \mathrm{S} / \mathrm{cm}$; portable conductivity meter), $\mathrm{pH}$ (portable $\mathrm{pH}$ meter), turbidity (NTU; portable turbidimeter), suspended solids (mg/L; Apha, 2005) and chlorophyll- $a(\mu \mathrm{g} / \mathrm{L}$; Golterman et al., 1978).

\section{Laboratory analysis}

Samples were concentrated to $100 \mathrm{ml}$ and then 20 sub-samples were taken with a Hensen-Stempell pipette $(2.5 \mathrm{ml})$ and counted in a Sedgewick-Rafter chamber, under an Olympus CX 41 microscope, at a $10 \times$ to $100 \times$ magnification range. For analysis of testate amoebae, only organisms with protoplasm stained with Rose Bengal were identified, assuming that the organisms were alive when the samples were taken. The identification of testate amoebae was based on the following literature: Vucetich (1973), Ogden \& Hedley (1980), Velho et al. (1996), Velho \& Lansac-Tôha (1996), Alves et al. (2007), Nicholls (2007) and Souza (2008). Rotifers were identified with the aid of the following literature: Koste (1978), Nogrady \& Pourriot (1995), Segers (1995) and Smet (1996).

\section{Data analysis}

Species richness (number of species), Shannon Diversity Index (H') and evenness (E) were calculated from the sample data for each site
(Magurran, 1988). To investigate the differences in the zooplankton structure between hydrological periods, the abundance, richness, diversity and evenness of testate amoebae and rotifers communities were evaluated by one-way analysis of variance (one-way ANOVA), with level of significance of $p<0.05$ (Sokal \& Rohlf, 1991). Normality and homoscedasticity (homogeneity of variance) were previously checked by the Shapiro-Wilk and Levene tests, respectively.

The relationship between environmental variables and testate amoebae and rotifers species was explored by means of a Canonical Correspondence Analysis (CCA) (Ter-Braak, 1986). Species abundance data were $\log$ transformed $[\log (x+1)]$ to reduce the effect of rare species, since these species were considered the more representative of this environment. The significance of the CCA association was tested with a Monte Carlo permutation test (999 permutations; Borcard et al., 1992).

Beta diversity values were calculated using the Bray-Curtis dissimilarity index to evaluate the spatial variability of the planktonic community, considering the environments in hydrological periods. The Bray-Curtis index establishes the relationship between species abundance and environments, where the value of one (maximum) indicates identical samples and value of zero indicates that the samples have no species in common (Magurran, 2004). Statistical analyses were performed in the statistical environment $\mathrm{R}$ version 3.0.2 (R Development Core Team, 2011) using the Vegan R package version 2.0-6 (Oksanen et al., 2012).

\section{RESULTS}

Testate amoebae were represented by 46 species of 10 families; Difflugiidae was the most representative, with 13 species, followed by Arcellidae (10 species) and Centropyxidae (8 species). The most common species were Arcella vulgaris Ehrenberg, 1830, Centropyxis aculeata Ehrenberg, 1838, C. ecornis Ehrenberg, 1841 e Cyclopyxis kahli Deflandre, 1929. These species were more abundant during the high water period (Fig. 2a). On the other hand, rotifers were represented by 39 species of 13 families; Brachionidae 

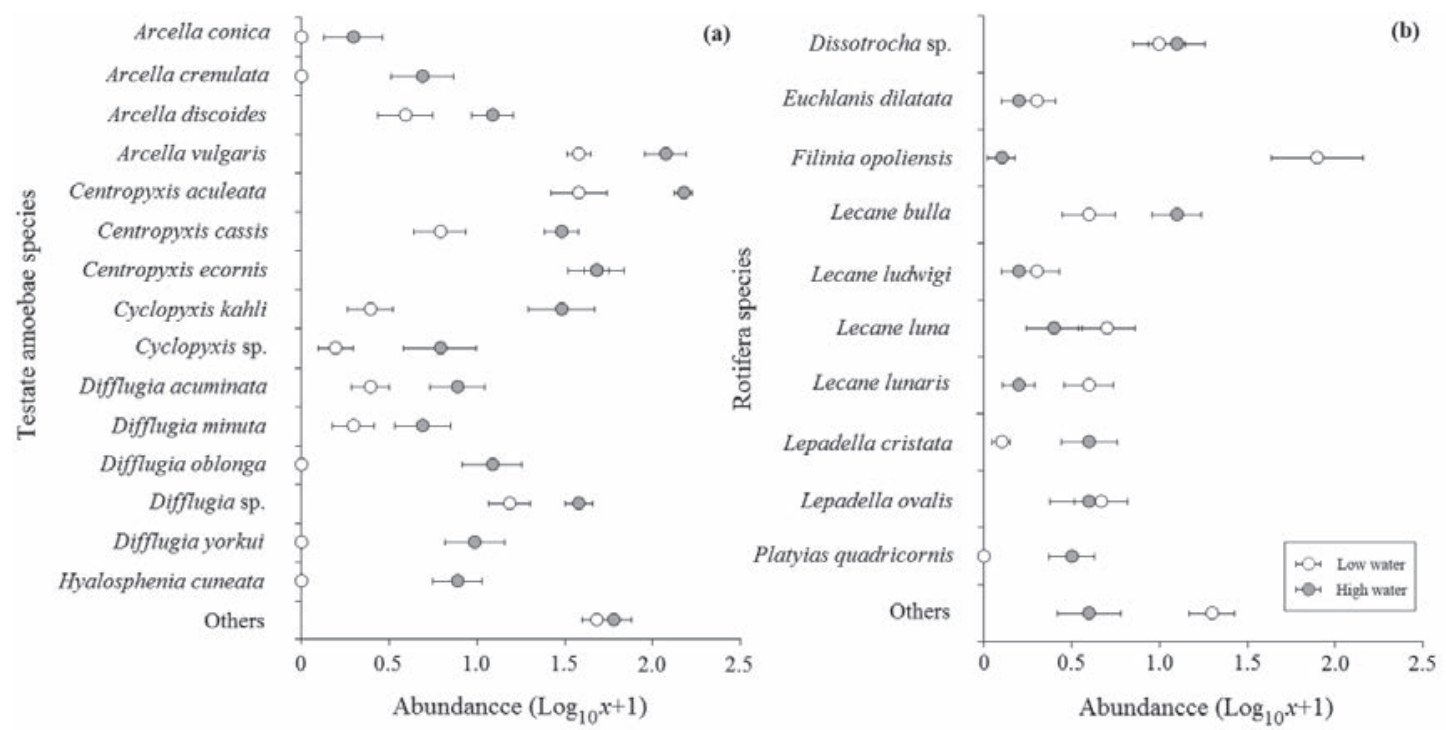

Figure 2. Abundance of the main species of testate amoebae (a) and rotifers (b) recorded during the hydrological periods. Circles = mean values of abundance; bars = standard error. Abundância das principais espécies de amebas testáceas (a) e rotíferos (b) registradas durante os períodos hidrológicos. Círculos = valores médios de abundância; barras = erro padrão.

and Lecanidae were the most representative, with 8 each species. The most common species were Filinia opoliensis (Zacharias, 1898), Dissotrocha sp., Lecane bulla (Gosse, 1851) and Lepadella ovalis (Müller, 1786). Community abundance was driven mainly by F. opoliensis (Fig. 2b) (see Table S1, available at www.limnetica.net/en/limnetica).

The Parnaíba River showed high variability between hydrological periods for most environmental variables. During the high water period, there were higher mean values for almost all environmental variables, except for water transparency, which had the highest mean value during the low water period (Table 1).

Table 1. Environmental data (Mean \pm SD) for the different hydrological periods. Dados ambientais (média $\pm S D$ ) para os diferentes períodos hidrológicos.

\begin{tabular}{lcc}
\hline Environmental variables & Low water & High water \\
\hline Chlorophyll- $a(\mu \mathrm{g} / \mathrm{L})$ & $0.11 \pm 0.27$ & $3.56 \pm 5.9$ \\
Conductivity $(\mu \mathrm{S} / \mathrm{cm})$ & $5.25 \pm 1.48$ & $9.86 \pm 4.94$ \\
Depth $(\mathrm{m})$ & $1.73 \pm 1.01$ & $2.29 \pm 1.03$ \\
Dissolved oxygen $(\mathrm{mg} / \mathrm{L})$ & $6.89 \pm 0.56$ & $7.27 \pm 0.24$ \\
$\mathrm{pH}$ & $5.45 \pm 0.17$ & $6.48 \pm 0.70$ \\
Suspended solids $(\mathrm{mg} / \mathrm{L})$ & $3.90 \pm 2.50$ & $54.46 \pm 77.07$ \\
Temperature $\left({ }^{\circ} \mathrm{C}\right)$ & $24.37 \pm 0.91$ & $27.80 \pm 1.52$ \\
Transparency $(\mathrm{m})$ & $1.11 \pm 0.30$ & $0.51 \pm 0.40$ \\
Turbidity $(\mathrm{NTU})$ & $6.60 \pm 2.65$ & $49.94 \pm 51.37$ \\
Water velocity $(\mathrm{m} / \mathrm{s})$ & $0.69 \pm 0.26$ & $0.83 \pm 0.22$ \\
\hline
\end{tabular}

The testate amoebae community had significantly higher values of abundance and species richness (Fig. 3a and Fig. 3b), but lower evenness (Fig. 3d), during the high water period. However, no significant differences in diversity were found between hydrological periods (Fig. 3c). The rotifer community had significantly higher values of abundance and species richness during the low water period (Fig. 3a and Fig. 3b), but a much higher evenness during high water (Fig. 3d). In the case of testate amoebae, no differences were found in terms of diversity. Overall, testate amoebae assemblages were richest and more diversified than rotifers, in both seasons (Fig. 3b and 3c).

According to the CCA, species abundance was correlated with environmental variables, as well as with spatial factors, during the hydrological periods analyzed. The first two CCA axes explained $68.6 \%$ of data variability. Some species were associated with environmental variables: Difflugia sp., Euchlanis dilatata Ehrenberg, 1832, Lecane lunaris (Ehrenberg, 1832), L. ludwigi (Eckstein, 1883) and Lepadella ovalis were positively correlated with water transparency and negatively correlated with turbidity, water temperature, water velocity and depth; Arcella conica (Playfair, 1918), A. crenulata Deflandre, 

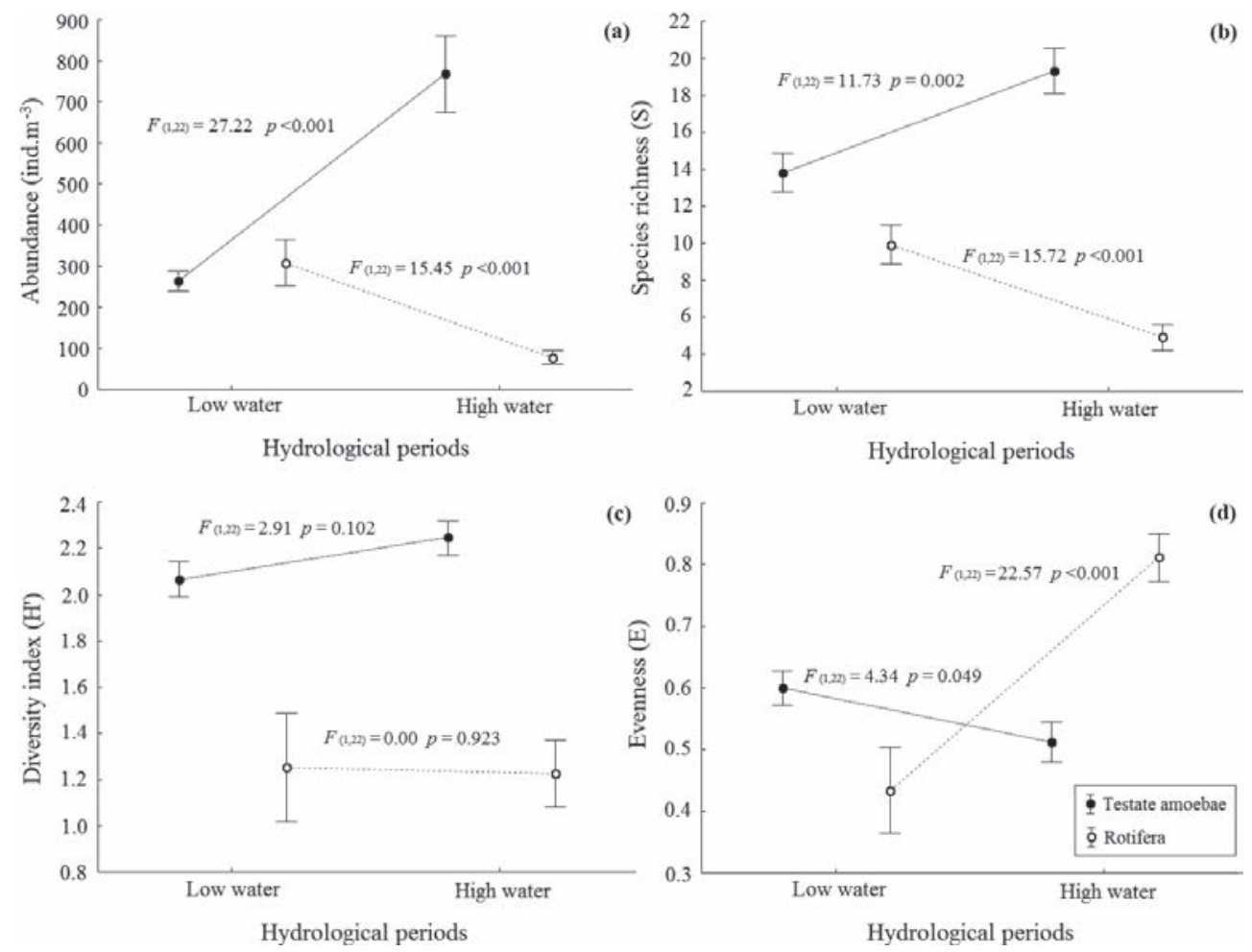

Figure 3. Abundance (a), richness (b), diversity (c) and evenness (d) of the testate amoebae and rotifers recorded during the hydrological periods. Circles = mean values of abundance, richness, diversity and evenness; bars = standard error. Abundância (a), riqueza (b), diversidade (c) e equitabilidade (d) de amebas testáceas e rotíferos registrados durante os períodos hidrológicos. Círculos = valores médios de abundância, riqueza, diversidade e equitabilidade; barras = erro padrão.

1928, A. discoides Ehrenberg, 1843, Centropyxis cassis (Wallich, 1864), Cyclopyxis sp. and Difflugia yorkui Nicholls, 2007 were positively correlated with turbidity, water temperature, water velocity and depth, and negatively correlated with water transparency; Arcella vulgaris, Centropyxis aculeata, C. ecornis, Dissotrocha sp., Filinia opoliensis and Lecane luna were negatively correlated with chlorophyll-a, dissolved oxygen, electrical conductivity, suspended solids and $\mathrm{pH}$; Cyclopyxis kahli, Difflugia acuminata Ehrenberg, 1832, D. minuta Rampi, 1950, D. oblonga Ehrenberg, 1838, Hyalosphenia cuneata Stein, 1857, Lecane bulla, Lepadella cristata (Rousselet, 1893) and Platyias quadricornis Ehrenberg, 1832 were positively correlated with chlorophyll- $a$, dissolved oxygen, electrical conductivity, suspended solids and pH (Fig. 4). These associations revealed significant correlations between zooplankton abundance and environmental variables (Permutest, Pseudo- $F=1.94 ; p=0.001$ ).
In general, according to the beta diversity using the Bray-Curtis index, the main alteration in the plankton community occurred during the low water period, with higher mean values of dissimilarity (0.54). In turn, greater similarity between communities was found during the high water period (0.63).

\section{DISCUSSION}

Our results showed that the presence of slackwaters and local environmental conditions are important factors influencing zooplankton community structure. In accordance with other studies (Thorp \& Mantovani, 2005; Nielsen \& Watson, 2008; Ning et al., 2009; Nielsen et al., 2010), our results confirm our initial hypotheses and suggest that slackwaters formed by the appearance of sandbars during the low water period represent a key habitats for the heterogeneity of the zooplankton structure in the Parnaíba 


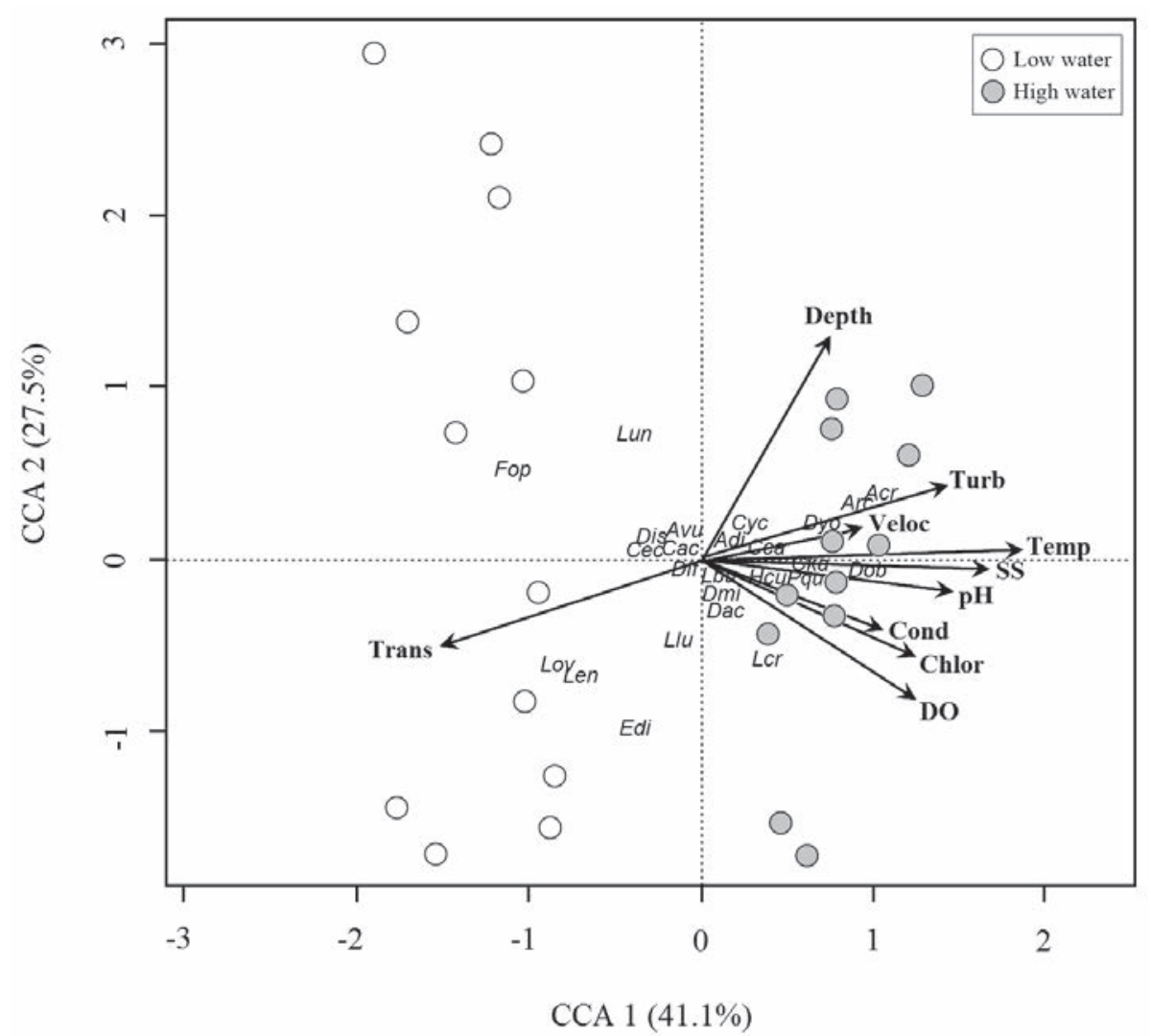

Figure 4. CCA results with the dispersion of the environmental variables and species abundance during the hydrological periods (abbreviations: Trans = water transparency; DO = dissolved oxygen; SS = Suspended solids; Chlor = chlorophyll- $a$; Cond = electrical conductivity; Temp = water temperature; Turb = turbidity; Veloc = water velocity; Testate amoebae: Aco = Arcella conica; Acr = Arcella crenulata; Adi = Arcella distenda; Avu = Arcella vulgaris; Cac = Centropyxis aculeata Cca = Centropyxis cassis; Cec = Centropyxis ecornis; Cka = Cyclopyxis kahli; Cyc = Cyclopyxis sp.; Dac = Difflugia acuminata; Dmi = Difflugia minuta; Dif = Difflugia sp.; Dob = Difflugia oblonga; Dyo = Difflugia yorkui; Hcu = Hyalosphenia cuneata; Rotifera: Dis = Dissotrocha sp.; Edi = Euchlanis dilatata; Fop = Filinia opoliensis; Lbu = Lecane bulla; Llu = Lecane ludwigi; Lun = Lecane luna; Len = Lecane lunaris; Lcr = Lepadella cristata Lov = Lepadella ovalis; Pqu = Platyias quadricornis). Resultados da CCA com a dispersão das variáveis ambientais e abundâncias das espécies durante os períodos hidrológicos (abreviaturas: Trans = transparência da água; DO = oxigênio dissolvido; SS = sólidos suspensos; Chlor = clorofila-a; Cond = condutividade elétrica; Temp = temperatura da água; Turb = turbidez; Veloc = velocidade da água).

River. In general, the community structure of testate amoebae and rotifers responded differently to periods of drought and flood. The appearance and disappearance of slackwater areas did not cause evident variability between hydrological periods in terms of species diversity, but this was clearly important for the variability in abundance, richness and evenness of the communities.

The high water period was important for increasing abundance and species richness of testate amoebae. Difflugiidae, Arcellidae and Centropyxidae were the most abundant and species-rich families. These families are consid- ered common in plankton and are usually associated with sediment and littoral vegetation, and transported to the water column with the suspension of sediment caused by increased water turbulence, especially during periods of floods (Alves et al., 2012; Lansac-Tôha et al., 2014; Arrieira et al., 2015; Schwind et al., 2016a). The decreased abundance and species richness of testate amoebae during the low water period may be related to the emergence of sandbars that promote the formation of slackwaters. As such, these areas may cause a buffer effect for suspension of organisms from benthic and littoral zones. 
On the other hand, the abundance and richness of rotifers were positively affected by the emergence of sandbars in the river channel. Brachionidae and Lecanidae were the most species-rich families of rotifers, but, the community abundance during the low water period was mainly driven by Filinia opoliensis (family Trochosphaeridae). Brachionidae and Trochosphaeridae species usually have planktonic habits, while Lecanidae species are related to benthic and littoral zones, occasionally occurring in plankton when migrating between these zones (Almeida et al., 2009; Lansac-Tôha et al., 2009; Picapedra et al., 2017). Once the slackwaters are formed, they buffer flow disturbances (Nielsen et al., 2010) and promote suitable conditions for the establishment of organism with planktonic habits. Apart from this, the high adaptability and capacity of rapid colonization of rotifers (Pourriot, 1977; Lansac-Tôha et al., 2009; Medeiros et al., 2011) favors the colonization of these newly formed habitats. By contrast, the disappearance of slackwater areas during the high water promoted a decline in species abundance and richness due to the presence of rigorous physical conditions in the environment (greater suspension of material organic and turbulence, and shorter water retention time) that hinder the establishment of these organisms.

Supporting our findings, the CCA evidenced a strong association of environmental variables with the two hydrological periods. Among testate amoebae, species of the genus Arcella and Difflugia were the most abundant during the high water period and exhibited strong associations with increased water velocity and turbidity. Studies indicate that greater turbulence and suspension of large sediment loads in the water column act as regulatory factors important to the zooplankton structure (Thorp \& Mantovani, 2005; Sluss et al., 2008). Moreover, the presence of gas vacuoles to float (Štěpánek \& Jiří 1958) and low density of the shells (Schönborn, 1962) facilitates the displacement of these protozoa to the plankton (Lansac-Tôha et al., 2014; Schwind et al., 2016b).

The results also showed that chlorophyll- $a$ was positively linked to several species of testate amoebae during the high water period. The avail- ability of chlorophyll- $a$ is one of the major influences on species distributions (Schwind et al., 2016b). This is because chlorophyll- $a$ is directly linked to food resources in aquatic ecosystems (Bastidas-Navarro \& Modenutti, 2007). Thus, chlorophyll- $a$ can be considered an important factor in the increased abundance of these organisms. Testate amoebae were also associated with higher temperature and $\mathrm{pH}$ values. Possibly, a decrease of temperature during the low water period possibly resulted in decreased metabolic rates of testate amoebae and consequent low feed rates in contrast to the high water period (Torres, 1996; Arrieira et al., 2015). In turn, a greater amount of organic matter was loaded into the river bed with floods. This, combined with higher temperatures, led to greater decomposition of organic matter, resulting in increased acidification of the environment during that period, reinforcing the abundance of species that prefer this type of environment (Lamentowicz \& Mitchell, 2005).

Rotifers were associated with the low water period, which had the lowest values of turbidity, suspended solids and water velocity. This observation is in line with results of Claps et al. (2011), who suggested that high concentrations of particles negatively impact rotifer populations because such insoluble materials interfere with the filtration process. Floods cause major changes in the physical and environmental conditions. Typically deeper areas are more exposed to turbulent conditions in this period because of relatively high water velocity (Frenette et al., 2012; Massicotte et al., 2014), which often promotes high mortality or removal (washing-out) of the zooplankton from the environment. However, the gradual restoration of bed environmental conditions such as reduced sediment resuspension and the appearance of slackwaters enable the re-colonization of this environment (Baranyi et al., 2002). Studies have shown that rapid colonization of slackwaters by organisms happens due to drift (Casper \& Thorp, 2007; Nielsen \& Watson, 2008; Ning et al., 2009) and hatching of resting eggs (Ning, 2011).

The dissimilarity index of the beta diversity showed a greater dissimilarity in the low water period. The appearance of sandbars may be 
contributing to increase the community heterogeneity among environments, possibly promoting natural barriers that hinder the displacement of organisms from littoral and benthic zones to plankton. Greater dissimilarity between aquatic communities during the low water period has been also observed in floodplain environments (Thomaz et al., 2007). Otherwise, higher similarity in the community occurred during the high water period. Increased hydrological discharge results in washing of slackwater areas, resulting in the homogenization of environments and consequent greater similarity between their communities (Saunders \& Lewis, 1988; Nielsen \& Watson, 2008). During flooding, the homogenization effect of floods is considered to be a general pattern (Schwind et al., 2016b).

The responses of biota to the high natural variability on flow regime, which typifies rivers and streams in the semi-arid region of Brazil, is still poorly known. The major threats to aquatic biota in semi-arid rivers in Brazil are related to historical changes in regional climatic conditions caused by human occupation in this region, which have led to the intensification of arid conditions (Maltchik \& Medeiros, 2006; Medeiros et al., 2011). It is worth noting also that failure to recognize the importance of ecological processes and linkages between natural hydrological disturbances and the biodiversity of aquatic systems in semi-arid Brazil will lead inevitably to the extinction of species and the loss or disruption of natural patterns of flow in these environments (Maltchik \& Medeiros, 2006).

In this study, we show that slackwaters formed by the appearance of sandbars during the low water period in the Parnaíba River play an important role in structuring communities. We suggest that changes in environmental variables, especially the decrease in water velocity, offered suitable conditions to the establishment of rotifers. On the other hand, slackwater areas act as natural barriers, causing a decline in testate amoebae populations in plankton due to lower sediment suspension in these areas. The opposite effect was found during the high water period; with the disappearance of sandbars, populations of rotifers were not able to establish due to the higher water velocity, while testate amoebae were more abundant in the plankton in this period, because of the increased sediment suspension.

\section{ACKNOWLEDGMENTS}

We thank the Grupo de Pesquisas em Recursos Pesqueiros e Limnologia (GERPEL) of the Universidade Estadual do Oeste do Paraná (UNIOESTE) for providing logistical support for collecting and analysing materials and two anonymous reviewers for their valuable suggestions.

\section{REFERENCES}

ALMEIDA, V. L. S., E. W. DANTAS, M. MELO-JÚNIOR, M. C. BITTENCOURT-OLIVEIRA \& A. N. MOURA. 2009. Zooplanktonic community of six reservoirs in Northeast Brazil. Brazilian Journal of Biology, 69 (1): 57-65. http://dx.doi.org/10. 1590/S1519-69842009000100007

ALVES, G. M., F. A. LANSAC-TÔHA, L. F. M. VELHO, C. Y. JOKO \& D. M. COSTA. 2007. New records of testate lobose amoebae (Protozoa, Arcellinida) for the Upper Paraná River floodplain. Acta Limnologica Brasiliensia, 19 (2): 175-195.

ALVES, G. M., L. F. M. VELHO, D. M. COSTA \& F. A. LANSAC-TÔHA. 2012. Size structure of testate amoebae (Arcellinida and Euglyphida) in different habitats from a lake in the upper Paraná River floodplain. European Journal of Protistology, 48 (2): 169-177. http://dx.doi.org/10.1016/j.ejop.2011.10.004

APHA. 2005. Standard methods for the examination of water and wastewater. American Public Health Association. Washington.

ARRIEIRA, R. L., G. M. ALVES, L. T. F. SCHWIND \& F. A. LANSAC-TÔHA. 2015. Local factors affecting the testate amoebae community (Protozoa: Arcellinida; Euglyphida) in a Neotropical floodplain. Journal of Limnology, 74 (3): 444-452. http://doi.org/10. 4081/jlimnol.2015.1078

BARANYI, C., T. HEIN, C. HOLAREK, S. KECKEIS \& F. SCHIEMER. 2002. Zooplankton biomass and community structure in a Danube River floodplain system: effects of hydrology. Freshwater Biology, 47 (3): 
473-482. http://dx.doi.org/10.1046/j.1365-2427. 2002.00822.x

BASTIDAS-NAVARRO, M. \& B. MODENUTTI. 2007. Efecto de la estructuración por macrófitas y por recursos alimentarios en la distribución horizontal de tecamebas y rotíferos en un lago andino patagónico. Revista Chilena de Historia Natural, 80: 345-362. http://dx.doi.org/10.4067/S0716-078X20070 00300008

BERTANI, I., H. SEGERS \& G. ROSSETTI. 2011. Biodiversity down by the flow: new records of monogonont rotifers for Italy found in the Po River. Journal of Limnology, 69 (2): 321-328. http://dx.doi.org/10.4081/jlimnol. 2011.321

BEUCHLE, R., R. C. GRECCHI, Y. E. SHIMABUKURO, R. SELIGER, H. D. EVA, E. SANO \& F. ACHARD. 2015. Land cover changes in the Brazilian Cerrado and Caatinga biomes from 1990 to 2010 based on a systematic remote sensing sampling approach. Applied Geography, 58: 116-127. http://doi.org/ 10.1016/j.apgeog.2015.01.017

BORCARD, D., P. LEGENDRE \& P. DRAPEAU. 1992. Partialling out the spatial component of ecological variation. Ecology, 73 (3): 1045-1055. http://doi.org/10.2307/1940179 BRASIL. MINISTÉRIO DO MEIO AMBIENTE. SECRETARIA DE RECURSOS HÍDRICOS. 2006. Caderno da Região Hidrográfica do Parnaíba. MMA. Brasília.

CASPER, A. F. \& J. H. THORP. 2007. Diel and lateral patterns of zooplankton distribution in the St. Lawrence River. River Research and Applications, 23 (1): 73-85. http://doi.org/10. 1002/rra.966

CLAPS, M. C., N. A. GABELLONE \& H. H. BENÍTEZ. 2011. Seasonal Changes in the Vertical Distribution of Rotifers in a Eutrophic Shallow Lake with Contrasting States of Clear and Turbid Water. Zoological Studies, 50 (4): 454-465.

FRENETTE, J. J., P. MASSICOTTE \& J. F. LAPIERRE. 2012. Colorful niches of phytoplankton shaped by the spatial connectivity in a large river ecosystem: a riverscape perspective. Plos One, 7: e35891. http://doi.org/10. 1371/journal.pone.0035891
GOLTERMAN, H. L., CLYMO, R. S. \& M. A. M. OHNSTADT. 1978. Methods for physical and chemical analysis of freshwaters. Blackwell Scientific Publications. Oxford.

HILL, M. T., W. S. PLATTS \& R. L. BESCHTA. 1991. Ecological and geomorphological concepts for in stream and out-of-channel flow requirements. Rivers, 2 (3): 198-210.

HUMPHRIES, P., R. A. COOK, A. J. RICHARDSON \& L. G. SERAFINI. 2006. Creating disturbance: manipulating slackwaters in a lowland river. River Research and Applications, 22 (5): 525-542. http://doi.org/10.1002/ rra.920

KING, A. J. 2004. Density and distribution of potential prey for larval fish in the main channel of a floodplain river: pelagic versus epibenthic meiofauna. River Research and Applications, 20 (8): 883-897. http://doi.org/10. 1002/rra.805

KOSTE, W. 1978. Rotatoria. Die Rädertiere Mitteleuropas Ein Bestimmungswerk, begründet von Max Voigt Überordnung Monogononta. Gebrüder Borntraeger. Stuttgart.

LAHR, D. J. G., H. D. LAUGHINGHOUSE, A. M. OLIVERIO, F. GAO \& L. A. KATZ. 2014. How discordant morphological and molecular evolution among microorganisms can revise our notions of biodiversity on Earth. BioEssays, 36 (10): 950-959. http://doi.org/10. 1002/bies.201400056

LAMENTOWICZ, M. \& E. MITCHELL. 2005. The ecology of testate amoeba (Protists) in Sphagnum in north-western Poland in relation to Peatland ecology. Microbial Ecology, 50 (1): 48-60. http://doi.org/10.1007/s00248004-0105-8

LANSAC-TÔHA, F. A., C. C. BONECKER, L. F. M. VELHO, N. R. SIMÕES, J. D. DIAS, G. M. ALVES \& E. M. TAKAHASHI. 2009. Biodiversity of zooplankton communities in the Upper Paraná River floodplain: interannual variation from long-term studies. Brazilian Journal of Biology, 69 (2): 539-549. http://dx.doi.org/10.1590/S151969842009000300009

LANSAC-TÔHA, F. A., L. F. M. VELHO, N. R. SIMÕES, D. M. COSTA, G. M. ALVES. 2014. Structure of the testate amoebae com- 
munity in different habitats in a Neotropical Floodplain. Brazilian Journal of Biology, 74 (1): 181-190. http://dx.doi.org/10.1590/15196984.24912

LEVIN, S. 1992. The problem of pattern and scale in ecology. Ecology, 73 (6): 1943-1967. http://dx.doi.org/10.2307/1941447

LUCENA, L. C. A., T. X. MELO \& E. S. F. MEDEIROS. 2015. Zooplankton community of Parnaíba River, Northeastern Brazil. Acta Limnologica Brasiliensia, 27 (1): 118-129. http://dx.doi.org/10.1590/S2179-975X3214

MAGURRAN, A. E. 1988. Ecological diversity and its measurement. Croom Helm. London.

MAGURRAN, A. E. 2004. Measuring biological diversity. Blackwell Publishing. Oxford.

MALTCHIK, L. \& E. S. F. MEDEIROS. 2006. Conservation importance of semi-arid streams in north-eastern Brazil: implications of hydrological disturbance and species diversity. Aquatic Conservation: Marine and Freshwater Ecosystems, 16: 665-677. http://dx.doi.org/10. 1002/aqc.805

MASSICOTTE, P., J. J. FRENETTE, R. PROULX, B. PINEL-ALLOUL \& A. BERTOLO. 2014. Riverscape heterogeneity explains spatial variation in zooplankton functional evenness and biomass in a large river ecosystem. Landscape Ecology, 29 (1): 67-79. http://doi.org/10.1007/s10980-0139946-1

MEDEIROS, E. S. F., N. P. NOIA, L. C. ANTUNES, T. X. MELO. 2011. Zooplankton composition in aquatic systems of semi-arid Brazil: spatial variation and implications of water management. Pan-American Journal of Aquatic Sciences, 9 (4): 290-232.

NICHOLLS, K. H. 2007. Descriptions of Phryganella laurentiana n. sp. and Difflugia yorkui n. sp. two new species of testate amoebae from boreal forest wetlands in Ontario, Canada. Acta Protozoologica, 46 (1): 65-72.

NIELSEN, D. L., G. WATSON \& R. PETRIE. 2005. Microfaunal communities in three lowland rivers under differing flow regimes. Hydrobiologia, 543 (1): 101-111. http://doi.org/ 10.1007/s10750-004-6946-9

NIELSEN, D. L. \& G. WATSON. 2008. The response of epibenthic rotifers and microcrus- tacean communities to flow manipulations in lowland rivers. Hydrobiologia, 603 (1): 117-128. http://doi.org/10.1007/s10750-0079251-6

NIELSEN, D. L., H. GIGNEY \& G. WATSON. 2010. Riverine habitat heterogeneity: the role of slackwaters in providing hydrologic buffers for benthic microfauna. Hydrobiologia, 638 (1): 181-191. http://doi.org/10.1007/s10750009-0039-8

NING, N. S. P., D. L. NIELSEN, W. L. PAUL, T. J. HILLMAN \& P. J. SUTER. 2009. Microinvertebrate dynamics in riverine slackwater and mid-channel habitats in relation to physico-chemical parameters and food availability. River Research and Applications, 26 (3): 279-296. http://doi.org/10.1002/rra.1266

NING, N. S. P. \& D. L. NIELSEN. 2011. Community structure and composition of microfaunal egg bank assemblages in riverine and floodplain sediments. Hydrobiologia, 661 (1): 211-221. http://doi.org/10.1007/s10750-0100525-Z

NOGRADY, T. \& R. POURRIOT. 1995. Rotifera: The Notommatidae. Guides to the identification of the microinvertebrates of the continental waters of the world. SPB Academic Publishing. The Hague.

OGDEN, C. G. \& R. H. HEDLEY. 1980. An atlas of freshwater testate amoebae. University Press. Oxford.

OKSANEN, J., F. G. BLANCHET \& R. KINDT. 2012. Vegan: Community Ecology Package. $\mathrm{R}$ package version 2.0-6. http://vegan.r-forge. r-project.org

PACE, M. L., S. E. G. FINDLAY \& D. LINTS. 1992. Zooplankton in advective environments: the Hudson River community and a comparative analysis. Canadian Journal of Fisheries and Aquatic Sciences, 49 (5): 1060-1069. http://doi.org/10.1139/f92-117

PEEL, M. C., B. L. FINLAYSON \& T. A. MCMAHON. 2007. Updated world map of the Koppen-Geiger climate classification. Hydrology and Earth System Sciences, 11: 1633-1644. http://doi.org/10.5194/hess-111633-2007

PENNAK, R. W. 1953. Fresh-water invertebrates of the United States. Ronald Press. New York. 
PICAPEDRA, P. H. S., C. FERNANDES \& F. A. LANSAC-TÔHA. 2017. Zooplankton community in the Upper Parnaíba River (Northeastern, Brazil). Brazilian Journal of Biology, 77 (2): 402-412. http://dx.doi.org/10.1590/15196984.20215

POURRIOT, R. 1977. Food and feeding habits of Rotifera. Archiv für Hydrobiologie, 8: 213-260.

R DEVELOPMENT CORE TEAM. 2011. $R$ : A Language and Environment for Statistical Computing. R Foundation for Statistical Computing. http://www.r-project.org

SAUNDERS, J. F. I. \& W. M. LEWIS JR. 1988. Zooplankton abundance and transport in a tropical white-water river. Hydrobiologia, 162: 147-155. http://doi.org/10.1007/BF000 14537

SCHÖNBORN, W. 1962. Über planktismus und ziklomorphose bei Difflugia limnetica (Levander) Pénard. Limnologica, 1: 21-34.

SCHWIND, L. T. F., R. L. ARRIEIRA, J. D. DIAS, N. R. SIMÕES, C. C. BONECKER, F. A. LANSAC-TÔHA. 2016a. The structure of planktonic communities of testate amoebae (Arcellinida and Euglyphida) in three environments of the Upper Paraná River basin, Brazil. Journal of Limnology, 75 (1): 78-89. https://doi.org/10.4081/jlimnol.2015.1180

SCHWIND, L. T. F., R. L. ARRIEIRA, T. MANTOVANO, C. C. BONECKER \& F. A. LANSAC-TÔHA. 2016b. Temporal influence on the functional traits of testate amoebae in a floodplain lake. Limnetica, 35 (2): 355-364.

SEGERS, H. 1995. Rotifera: The Lecanidae (Monogononta). Guides to the identification of the microinvertebrates of the continental waters of the world. SPB Academic Publishing. The Hague.

SEGERS, H. 2008. Global diversity of rotifers (Rotifera) in freshwater. Hydrobiologia, 595: 49-59. http://doi.org/10.1007/978-1-40208259-7_6

SLUSS, T. D., G. A. COBBS \& J. H. THORP. 2008. Impact of turbulence on riverine zooplankton: a mesocosm experiment. Freshwater Biology, 53 (10): 1999-2010. http://doi.org/10.1111/j.1365-2427.2008. 02023.x
SMET, W. H. 1996. Rotifera: The Proalidae (Monogononta) - Guides to the identification of the microinvertebrates of the continental waters of the world. SPB Academic Publishing. The Hague.

SOKAL, R. R. \& F. J. ROHLF. 1991. Biometry: The principles and practice of statistics in biological research. W. H. Freeman and Company. New York.

SOUZA, M. B. G. 2008. Guia das tecamebas Bacia do rio Peruaçu, Minas Gerais Subsídio para conservação e monitoramento da Bacia do Rio São Francisco. Editora UFMG. Belo Horizonte.

ŠTĚPÁNEK, M. \& J. JIŘÍ. 1958. Difflugia gramen Pénard, Difflugia gramen var. achlora Pénard and Difflugia gramen f. globulosa f. n. (Morphometrical and Statistical study). Hydrobiologia, 10: 138-156. http://doi.org/10. 1007/BF00142184

TER-BRAAK, C. J. F. 1986. Canonical correspondence analysis: a new eigenvector technique for multivariate direct gradient analysis. Ecology, 67 (5): 1167-1179. http://doi.org/ $10.2307 / 1938672$

THOMAZ, S. M., L. M. BINI \& R. L. BOZELLI. 2007. Floods increase similarity among aquatic habitats in river-floodplain systems. Hydrobiologia, 579 (1): 1-13. https://doi.org/10. 1007/s10750-006-0285-y

THORP, J. H. \& S. MANTOVANI. 2005. Zooplankton of turbid and hydrologically dynamic prairie rivers. Freshwater Biology, 50 (9): 1474-1491. http://doi.org/10.1111/j. 1365-2427.2005.01422.x

THRUSH, S. F., D. C. SCHNEIDER, P. LEGENDRE, R. B. WHITLATCH, P. K. DAYTON, J. E. HEWITT, A. H. HINES, V. J. CUMMINGS, S. M. LAWERIE, J. GRANT, R. D. PRIDMORE, S. J. TURNER \& B. H. MCARDLE. 1997. Scaling-up from experiments to complex ecological systems: where to next? Journal of Experimental Marine Biology and Ecology, 216 (1-2): 343-354. http://doi.org/10 1016/S0022-0981(97)00099-3

TORRES, V. S. 1996. Estudos sobre Difflugia lobostoma Leidy (Protista, Rhizopoda, Testacealobosea). Revista Brasileira de Zoologia, 13: 475-487. http://dx.doi.org/10.1590/S0101- 
81751996000200016

VELHO, L. F. M., F. A. LANSAC-TÔHA \& M. SERAFIM-JÚNIOR. 1996. Testate amoebae (Rhizopodea-Sarcodina) from zooplankton of the high Paraná river floodplain, State of Mato Grosso do Sul, Brazil: I Families Arcellidae and Centropyxidae. Studies on Neotropical Fauna Environment, 31 (1): 135-150.

VELHO, L. F. M. \& F. A. LANSAC-TÔHA. 1996. Testate amoebae (Rhizopodea-Sarcodina) from zooplankton of the high Paraná river floodplain, State of Mato Grosso do Sul, Brazil: II Family Difflugiidae. Studies on
Neotropical Fauna Environment, 31 (3): 179-192.

VUCETICH, M. C. 1973. Estudio de tecamebianos argentinos, em especial los del dominio pampasico. Revista del Museo de La Plata, 11: 287-332.

WARD, J.V. \& J. A. STANFORD. 1995. The serial discontinuity concept: extending the model to floodplain rivers. Regulated Rivers-research \& Management, 10 (2-4): 159-168. http://dx.doi.org/10.1002/rrr. 3450100211 